\title{
Current Research Trends on Interrelationships of Eco-Innovation and Internationalisation: A Bibliometric Analysis
}

\author{
Paulius Šūmakaris ${ }^{1}$, Deniss Ščeulovs ${ }^{2}$ and Renata Korsakiene் ${ }^{1, *(1)}$ \\ 1 Faculty of Business Management, Vilnius Gediminas Technical University, Saulètekio al. 11, \\ LT-10223 Vilnius, Lithuania; paulius@sumakaris.lt \\ 2 Faculty of Engineering Economics and Management, Riga Technical University, Kalnciema Street 6, \\ Room 408, LV-1048 Riga, Latvia; deniss.sceulovs@rtu.lv \\ * Correspondence: renata.korsakiene@vgtu.lt
}

Received: 30 March 2020; Accepted: 22 April 2020; Published: 27 April 2020

\begin{abstract}
In this paper, bibliometric analysis is conducted on eco-innovation and internationalisation, since in the scientific literature, both research fields have been considered as being interrelated. Although the adoption of eco-innovation and internationalisation are risky processes, they reduce competitive risk and increase performance in a highly competitive business environment. The main objective of this study is to identify current research trends on the interrelationships of eco-innovations and internationalisation as well as the main areas of knowledge and to provide a general overview of research streams that can be classified using by papers, authors and journals found in the Web of Science database. In total, 1677 publications published between 1991 and 2020 related to eco-innovations and internationalisation were taken into consideration. For the visualisation of bibliographic material, VOSviewer software was used. These findings provide valuable insights by revealing the trends and highlighting the possible research streams for future investigations in the field of eco-innovations and internationalisation research.
\end{abstract}

Keywords: eco-innovation; internationalisation; risk; performance; bibliometric analysis

\section{Introduction}

The total quantity of scientific research literature on a particular field of study can often be overwhelming (van Nunen et al. 2018) and continues to rise, which makes it difficult for scientists to have a structured overview of important information. Bibliometrics is a valuable tool for a literature analysis that can efficiently reveal the latest advances in a specific field of research (Wang et al. 2014). The worldwide shift towards sustainable development and environmental integrity makes it necessary for companies to take adaptation and risk management actions in order to reduce their environmental impact while developing products and services. There is a solidarity among academics and market professionals regarding the changes needed in current business practices and how these changes affect natural and social environments. Due to the environmental issues and increased focus on sustainability, eco-innovations are gaining more and more attention. This concept has been discussed in the majority of the United Nations (UN) sustainable development goals (SDGs) and thus, to achieve these goals, eco-innovation must be involved, i.e., innovations that reduce environmental and social impacts while causing disruptions and improvements to existing production models (Lopes Santos et al. 2019).

The growing demand from consumers and world-wide regulatory requirements for eco-friendly products and services challenge companies to adopt eco-innovations not only in their domestic markets but also for exporting companies in their foreign markets, making both internationalisation 
and eco-innovation more a necessity than a choice (Hojnik et al. 2018). Notably, eco-innovation is considered to be a source of global competitive advantage and becomes a key factor in increasing the exporting profitability of the firms that utilize it (Martínez-Román et al. 2019). This innovation enables internationalisation and facilitates companies' adaptation to a global competitive environment. Furthermore, the positive impact of eco-innovation on firms' financial performance (Marcus 2015) through results such as cost reductions and an increase of sales has been observed (Ociepa-Kubicka and Pachura 2017). Internationalisation and development of eco-innovations may bring economic growth to companies and improve their competitive advantage, however, it may give rise to uncertainties and are assumed to be risky processes (de Perea et al. 2019). The development of new products or processes implies a high level of risk and paradoxically this type of risk can exert a negative impact on companies' internationalisation (Martínez-Román et al. 2019). Thus, the outcomes of eco-innovation and internationalisation might demonstrate the difference between the expected result and a negative result (Inanoglu and Jacobs 2009). While eco-innovation is riskier in terms of investments (Cainelli et al. 2015), the risk level is directly proportional to the level of innovativeness. Thus, the firms might encounter financial risk, especially with eco-innovative activities and a low level of acceptance in the market (Ociepa-Kubicka and Pachura 2017; Martínez-Román et al. 2019) while expanding internationally. Consequently, the higher costs of internationalisation will negatively influence the performance of the firms that experience these challenges (Nguyen et al. 2019). In spite of prevailing risk, businesses are encouraged to invest into innovations (Qi et al. 2020) by considering financial eco-innovation, i.e., a specific mechanism bridging the financing of eco-innovation and sustainability (González-Ruiz et al. 2018). Moreover, these scholars suggest making eco-innovation the main focal point of a firm's strategy and subsequently, diminishing their risk (Munodawafa and Johl 2019). Thus, aiming to manage a risk of eco-innovation and internationalisation, the interrelationship between eco-innovation and internationalisation requires deeper investigation.

\subsection{Eco-Innovation}

Over the last three decades, the eco-innovation concept has been embedded in most sustainability research documents. Although the term was defined in 1996, most eco-innovation research publications have been published after 2009 (Kuo and Smith 2018). Eco-innovation (sometimes defined as environmental or green innovation) is usually defined as innovation that results in a reduction of environmental impact. Furthermore, as compared to traditional forms of innovation, eco-innovation emphasises the companies' mitigation of negative impacts and are associated with environmental benefits (Liao and Tsai 2019). Over the last 30 years, other terms have been used to define the strategy of eco-innovation, such as green innovation, environmental innovation, sustainable innovation, etc. The main methods used to extend beyond traditional forms of innovation over the time emphasise social and environmental impacts, changes of business models that involve the consumption of materials, energy and water (Lopes Santos et al. 2019). Moreover, eco-innovation can be adopted by companies or non-profit organisations at different social, technological, institutional or organisational levels (González-Ruiz et al. 2018). Notably, the definitions of eco-innovation are based on the concept of "traditional innovation with reduction of environmental impact" and reflect regulatory requirements for companies to consider the consequences of their operations (Lopes Santos et al. 2019).

Organisation for Economic Cooperation and Development (OECD) defines eco-innovation as "the implementation of a new or significantly improved product (good or service), or process, a new marketing method, or a new organisational method for business practices, workplace organisation or external relations, that results in a reduction of environmental impact, no matter whether that effect is intended or not and the scope of eco-innovation may go beyond the conventional organisational boundaries and involve broader social arrangements that trigger changes in existing socio-cultural norms and institutional structures". Furthermore, Organisation for Economic Cooperation and Development (OECD) distinguished three main facets of eco-innovation: 1. Targets, such as products, processes (rely on technological development), marketing methods, organisations and institutions 
(rely on non-technological development). 2. Mechanisms, that involve practice modifications, redesign and new alternatives, or the creation of entirely new practices. 3. Impacts, which defines how the eco-innovation affects environmental conditions.

The European Commission grouped 16 indicators into five dimensions determining eco-innovation: inputs, activities, outputs, resource efficiency and socio-economic outcomes (Spaini et al. 2018). Paraschiv et al. (2012) argue that one of the main factors influencing companies' sustainable development is eco-innovation, which plays a key role in achieving global corporate sustainability goals. Hence, eco-innovation is one of the key factors involved in achieving global sustainability objectives and moving industries towards sustainable development, with important potential benefits for innovative companies, industries and even entire economies (Paraschiv et al. 2011). However, the main barrier towards implementing eco-innovation is financial factors and a lack of sufficient resources (Przychodzen and Przychodzen 2015).

In the context of sustainable development, eco-innovations are essential for organisations seeking to align themselves with international concerns related to environmental protection, human rights and the wealth of their employees (Paraschiv et al. 2012). In order to achieve the SDGs, eco-innovation has been proposed as an effective solution to help companies to reduce their negative environmental impacts (Kuo and Smith 2018). In this study, the term "eco-innovation" is in line with UN's SDGs view and emphasises the ecological dimension of these goals.

\subsection{Internationalisation}

Internationalisation is not as new a phenomenon as eco-innovation. As the subject of the research, internationalisation has been developing for more than sixty years (Głodowska et al. 2019); however, the number of scientific publications continues to rise. Though initial studies considered large corporations, later on the discussions have been expanded in the small business context (Korsakiene et al. 2019a). Moreover, internationalisation has been analysed in many scientific disciplines. Thus, various approaches to study the phenomenon were applied stemming from management, economics, entrepreneurship, etc.

The traditional internationalisation approaches such as the Uppsala model (Vahlne and Johanson 2013) defines internationalisation as the process of acquiring, integrating and utilising knowledge and competence in international operations through increased participation in international markets. Meanwhile, new investigations continue to study the phenomenon and define internationalisation as a multi-stage process which also has a curvilinear relationship with a firm's performance (Nguyen et al. 2019). While business, economic and social environments have been changing over time, the different phases and dimensions of internationalisation have been emerging (Deng et al. 2020). Thus, the scholars treat the internationalisation process as encompassing the opportunities for emerging foreign firms to build various relationships (Deng et al. 2020). Moreover, previous investigations in the context of smaller firms disclosed various paths of growth, such as through the improvement of products, expansion of market share through innovation or the expansion of foreign market share through exports i.e., internationalisation (Henley and Song 2019).

Finally, internationalisation is assumed to be a strategic decision through which companies seek increased involvement in global markets and foreign sales. Though scientific discussion on internationalisation has triggered a number of studies, the majority of studies rely on the degree of a company's internationalisation, i.e., the proportion of their export sales to total sales, as a single measurement of internationalisation (Genc et al. 2019; Korsakienè et al. 2019b). Moreover, export performance appears to be the main indicator used to observe internationalisation of the companies, especially in the small business context.

\subsection{Interrelationships of Eco-Innovations and Internationalisation}

The importance of internationalisation and eco-innovations in organisational performance has triggered scientific debates. Apparently, innovation capabilities developed by firms impact strategic 
behaviour, including their stance towards internationalisation (Mi et al. 2020). Many authors, with evidence from different countries and product groups, emphasise the importance of innovation in order to increase export performance and competitiveness (Priede and Pereira 2015). For instance, investigations performed in Australia revealed that eco-innovation increased international performance (Ratten 2018). The studies revealed that companies that have international operations are more innovative than those do not, highlighting the fact that exporters are significantly more likely to introduce product, process and management innovation (Shearmur et al. 2015). Therefore, organisations must focus on two approaches. First, the companies have to innovate to exploit technological opportunities. Second, the companies have to respond to the changes in demand and lifestyles of consumers (Bossle et al. 2016). In addition, the "green barrier" hinders companies' collaborations with international organisations unless they meet all the necessary ecological regulatory requirements.

While some studies investigated the direct relationship between innovation and internationalisation (Chiarvesio et al. 2015), other studies investigated the mediation effect of eco-innovation. Juniati et al. (2019) argues that eco-innovation has an important mediating effect on the relationship between internationalisation and performance in Malaysian multinational firms. According to the authors, the relationship between internationalisation and eco-innovation enables companies to achieve better performance and competitiveness, and also contributes to their environmental and social improvements. Juniati et al. (2019) suggests that internationalisation is a driving force for companies to learn and implement eco-innovations. Moreover, internationalisation with assimilated eco-innovations enable companies to achieve better performance. Thus, it was confirmed by multiple studies that the companies are encouraged to expand business horizons to achieve cost efficiencies, as well as technological and business function improvements. However, the study only considered large multinational firms and did not take into account other variables, which is the limitation for large multi-national corporation studies (Juniati et al. 2019). Meanwhile, the study performed by Hojnik et al. (2018) investigated 151 Slovenian internationalized companies and revealed that companies which implement a learning process based on internationalisation activities and eco-innovation initiatives improve their economic performance.

The scholars discussing the organisational learning perspective aim to shed light on the relationship between internationalisation and eco-innovation. They argue that when companies export, they gain information on foreign customers' needs and regulatory demands, as well as an improved understanding of foreign markets, partners, competitors and their technological gaps. Knowledge acquisition is one of the key factors affecting the internationalisation and learning process, which lets companies incorporate gained knowledge into firm-level routines and improve their product, process, and organisational innovations. These findings complement the "learning by exporting" stream of research, which suggests that exporters learn from foreign customers and partners by implementing new production technologies and subsequently innovate. Thus, the findings of Hojnik et al. (2018) indicate that eco-innovation adoption and environmental sustainability are significant and comprise the key drivers for serving foreign markets. According to these scholars, internationalisation leads to the adoption of eco-innovation and the relationship between internationalisation and eco-innovation is stronger in medium-sized and large companies, especially in manufacturing companies, that operate in the business-to-consumer market and companies that are ISO14001 accredited. However, the study relied on the self-reported measurements provided by companies' environmental or quality managers, meaning further investigation needs to be done using more direct objective measurements (Hojnik et al. 2018).

\subsection{Purpose of the Study}

While considering the dynamics in economical, ecological and social environments, the research question is formulated as follows: what is the current state of knowledge about the interrelationships between eco-innovations and internationalisation and how it has been investigated? The purpose of this study is to disclose and provide a coherent overview of current research trends on the interrelationships between eco-innovations and internationalisation and to highlight the possible research streams for 
future investigations. To achieve the objective, we analyse the academic literature by adopting a bibliometric methodology, which offers a systematic and macroscopic overview of current knowledge. Bibliometric analysis is a technique for providing an extensive overview of large amounts of scientific literature in a particular field of research and can be used to evaluate the research trends and cooperation patterns involving authors, journals and countries $=$ (van Nunen et al. 2018). This paper contributes to the literature of eco-innovations and internationalisation by bringing the two together and using their core findings to study the interrelationships between them. The data in this study provides an overview on the research progress achieved in the streams of eco-innovations and internationalisation and it can help both researchers and professionals to identify the most influential authors, journals, countries and research topics.

\section{Materials and Methods}

Bibliometric analysis is a valuable tool for studying bibliographic materials by using quantitative methods. The method became very popular for the representation of summarised results of classified bibliography (Cancino et al. 2017). The method includes various steps that must be taken by researchers. These steps are pre-established through the research protocol and all possible sources of error (or bias) that can undermine the relevance of the study are considered (Pedro et al. 2018). The stages included in the research protocol of this study are presented in Figure 1. Moreover, before stage 1, the following research questions were formulated:

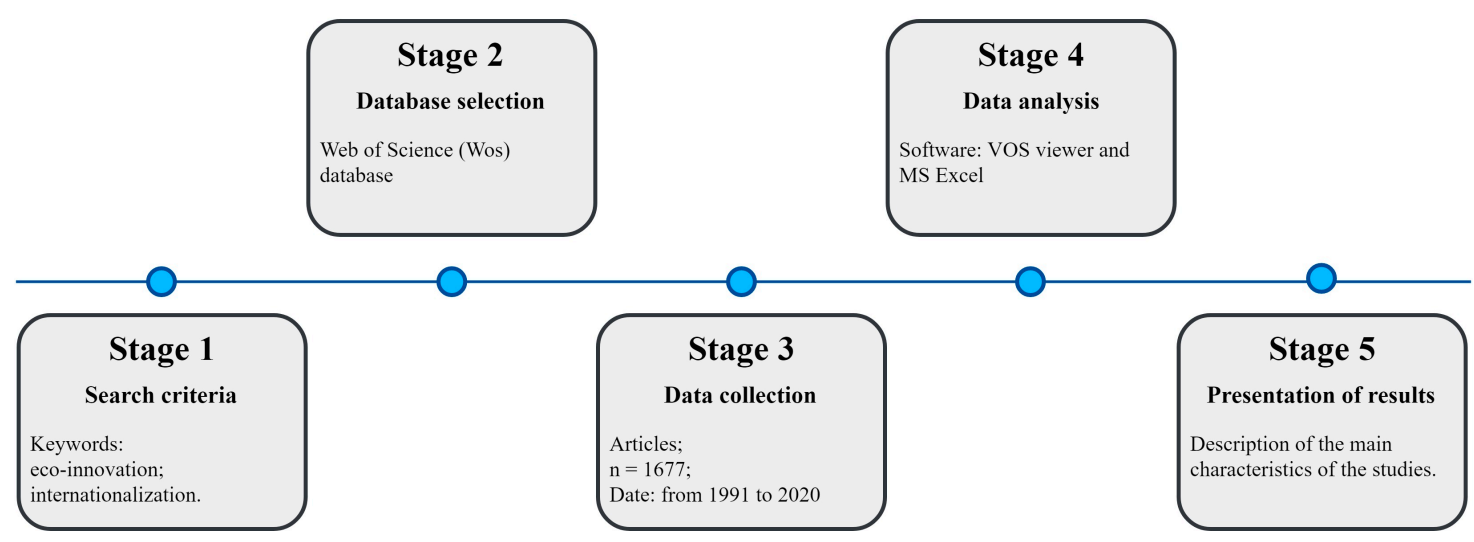

Figure 1. The five stages of bibliometric analysis.

RQ1: what is the output and growth trend of publications in the selected streams?

$R Q 2:$ which are the most influential countries and journals that are impacting the research streams?

$R Q 3:$ what is the relationship between internationalisation and eco-innovation and how it is being investigated?

\subsection{Stage 1: Search Criteria}

The first condition for the study was to rely on scientific papers that are investigating eco-innovation and internationalisation as the main concepts. This condition for the keywords was used for several reasons. Firstly, it aimed to ensure that the scientific literature is within the scope of this paper. Secondly, it aimed to ensure that this study did not divert away from the main research questions. Hence, numerous synonyms were used in conjunction with the main keywords and the initial search string was composed of three parts: the first focused on the ecological part using eco OR ecologic OR environment OR sustainable OR green, the second focused on innovations, using innovation and the last focused on internationalisation part, using internationalisation OR export. No quotation marks were included, however an asterisk was included to extract the synonyms. Notably, the filtering of general noun phrases, such as result, study, paper, etc. was crucial (Van Raan 2014), because these general meaning noun phrases tend to distort the structure of two-dimensional map due to their 
irrelevance compared to the research topic. This search results all had the selected terms identified in the title, the abstract and/or in the keywords of the publications with the indexes SCI-EXPANDED, SSCI, A\&HCI, CPCI-S, CPCI-SSH and ESCI.

\subsection{Stage 2: Database Selection}

This study included an information search using Web of Science (or WoS), which is one of the main scientific databases and is the most relevant scientific citation database. It is also a multidisciplinary database, indexing the most cited journals in the respective fields (Pedro et al. 2018), such as SCI-EXPANDED, SSCI, A\&HCI, CPCI-S, CPCI-SSH, BKCI-S, BKCI-SSH, ESCI, CCR-EXPANDED and IC (Dabić et al. 2019). Every publication in Web of Science includes many details such as the publication year, authors, addresses, title, abstract, journal, references, etc. (van Nunen et al. 2018).

\subsection{Stage 3: Data Collection}

The search was performed in April 2020. Only empirical research papers were included, as they featured the results of investigations on internationalisation and eco-innovation; therefore, the document type was selected as Article and included the period from 1991 to 2020. The preliminary results of the search in WoS were a total of 1841 articles. In order to analyse the selected keywords, the language filter was applied, which resulted in a total of 1677 papers found that were published in English from 1991 to 2020. Once the data search was finalised, we exported the results with all available information in the ".txt" format, which was used for the analysis.

\subsection{Stage 4: Data Analysis}

After data collection, the selected articles were assessed by considering the chosen streams prior to the data synthesis. This stage let us confirm the relevance of the study. The main ideas in the discovered texts were analysed and their relevance to the eco-innovation and internationalisation was studied.

For quantitative data analysis, the construction and visualisation of bibliometric networks (van Eck and Waltman 2017) was used by applying the free access VOSviewer (www.vosviewer.com) software. VOS viewer software provides a more general view of search results by generating two-dimensional maps based on bibliographic coupling, co-authorship, citation, co-citation, co-occurrence of keywords, authors and countries to visualise relationships between them (van Nunen et al. 2018; Cancino et al. 2017; Gall et al. 2015). The clustering method was used to identify different clusters, where each group is differently coloured (van Eck and Waltman 2017). The clusters were formed by selecting all papers that together are linked by a specified co-citation threshold. The interpretation of visualisation, in general, is as follows: the size of the circles represents the number of occurrences, the distance between two circles reveals similarities and relatedness, different colours mark separate clusters (van Nunen et al. 2018).

Cancino et al. (2017) describes the principles and explains that bibliographic coupling links two papers that cite the same third article. Co-citation is a method used to establish subject similarity between two documents. Meanwhile, co-authorship measures the degree of co-authorship between the most productive sources. Citation analysis focuses on the degree of citation similarity between two variables. Co-occurrence of author keywords shows the most common keywords and the network connections visualises the keywords that appear more frequently in the same papers (Van Raan 2014).

\subsection{Stage 5: Presentation of Results}

After data processing and analysis, only the final results and quantitative evaluation of the examined phenomenon are presented in the following sections. The detailed results and visualisations are provided in the results section. The discussion and conclusions sections follow. 


\section{Results}

\subsection{The Output and Growth Trend of Publications}

To answer RQ1, we measured the output of annual publications. The number of scientific papers is an important measurement for evaluating the development in a specific research discipline or a field. The publications related to eco-innovations and internationalisation increased over the analysed period (Figure 2). In total 1677 scientific documents were published during the years 1991-2020. There was only one publication in 1991. The number of publications remained limited until 2008 as compared to later years (less than 50 publications was published every year until 2009). From 2009, an increasing number of scientific papers was observed every year (with exception of 2010, $(n=45)$ ). A small jump was observed in $2011(n=79)$, while in a decline was observed in $2012(n=65)$. The number of publications continued to grow rapidly from 2012 until $2019(n=252)$. The publications from 2020 was not included in the Figure 1 due to the limited number of publications so far this year $(n=54)$, which distorts the trend.

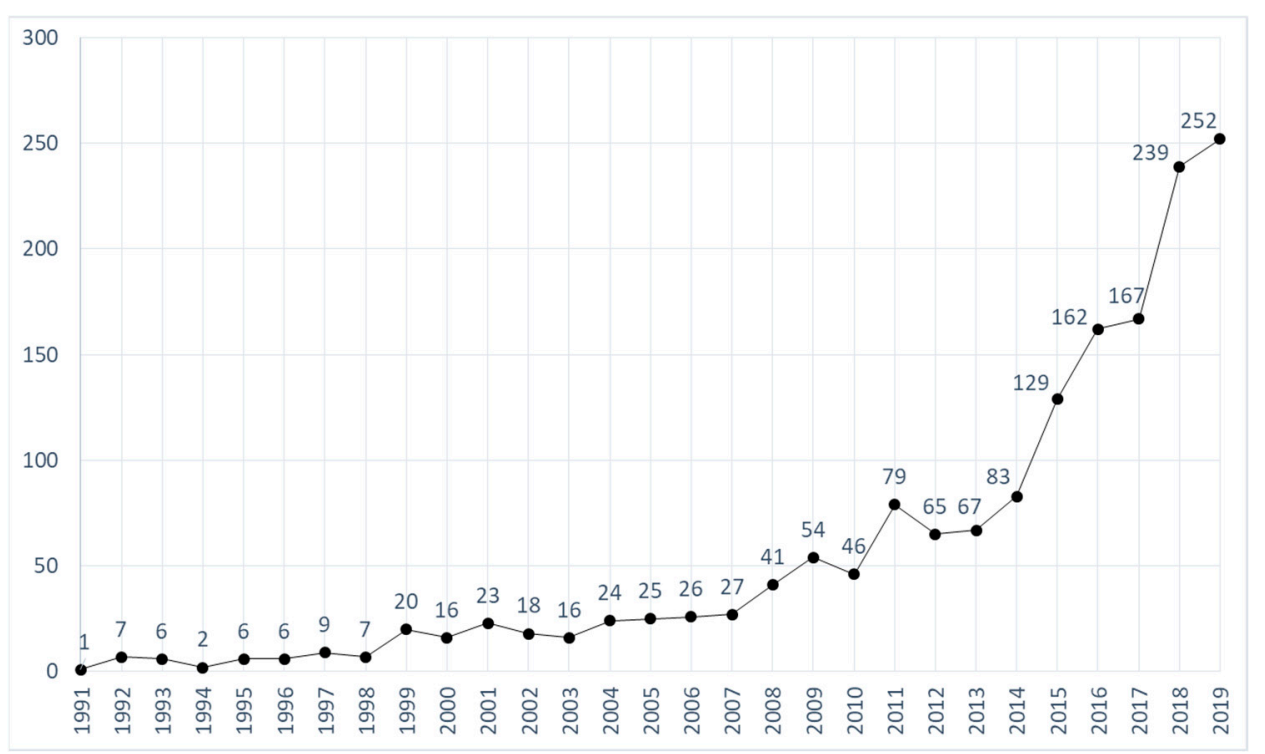

Figure 2. A number of publications related to eco-innovations and internationalisation by year.

\subsection{The Most Cited Publications}

The most cited and influential publications $(n=15)$ on eco-innovations and internationalisation are presented in Table 1. The most cited publication is published by E. F. Lambin and P. Meyfroidt "Global land-use change, economic globalisation, and the looming land scarcity" in 2011, (Proceedings of the National Academy of Sciences of the United States of America) and was cited 1097 times with the average citations per year of $n=121.89$. The second most cited publication is published by Q. Zhu and J. Sarkis "Relationships between operational practises and performance among early adopters of green supply chain management practices in Chinese manufacturing enterprises", published in 2004, (Journal of Operations Management) and was cited 999 times, with an average citations per year of $n=62.44$. The third most cited publication is published by J. L. Furman, M. E. Porter and S. Stern "The determinants of national innovative capacity" in 2002, (Research Policy) and was cited 803 times, with an average citations per year of $n=44.61$. 
Table 1. The most cited publications.

\begin{tabular}{|c|c|c|c|}
\hline Title & Author(s) & Journal & $\mathrm{Y} / \mathrm{C}^{*}$ \\
\hline $\begin{array}{c}\text { Global land-use change, economic globalization, and the } \\
\text { looming land scarcity }\end{array}$ & E. F. Lambin and P. Meyfroidt & $\begin{array}{l}\text { Proceedings of the National } \\
\text { Academy of Sciences of the } \\
\text { United States of America }\end{array}$ & $2011 / 1097$ \\
\hline $\begin{array}{l}\text { Relationships between operational practices and performance } \\
\text { among early adopters of green supply chain management } \\
\text { practices in Chinese manufacturing enterprises }\end{array}$ & Q. Zhu and J. Sarkis & $\begin{array}{l}\text { Journal of Operations } \\
\text { Management }\end{array}$ & 2004/999 \\
\hline The determinants of national innovative capacity & $\begin{array}{l}\text { J. L. Furman, M. E. Porter } \\
\text { and S. Stern }\end{array}$ & Research Policy & $2002 / 803$ \\
\hline $\begin{array}{l}\text { Land use transitions: Socio-ecological feedback versus } \\
\text { socio-economic change }\end{array}$ & E. F. Lambin and P. Meyfroidt & Land Use Policy & $2010 / 435$ \\
\hline Toward a spatial perspective on sustainability transitions & $\begin{array}{l}\text { L. Coenen, P. S. Benneworth } \\
\text { and B. Truffer }\end{array}$ & Research Policy & $2012 / 390$ \\
\hline $\begin{array}{l}\text { Subsidiaries and knowledge creation: the influence of the } \\
\text { MNC and host country on innovation }\end{array}$ & P. Almeida and A. Phone & Strategic Management Journal & $2004 / 386$ \\
\hline $\begin{array}{l}\text { International venturing by emerging economy firms: the } \\
\text { effects of firm capabilities, home country networks, and } \\
\text { corporate entrepreneurship }\end{array}$ & $\begin{array}{l}\text { D. W. Yiu, C. Lau and G. D. } \\
\text { Bruton }\end{array}$ & $\begin{array}{c}\text { Journal of International Business } \\
\text { Studies }\end{array}$ & $2007 / 375$ \\
\hline The geographic sources of foreign subsidiaries' innovations & T. S. Frost & Strategic Management Journal & $2001 / 362$ \\
\hline $\begin{array}{l}\text { International corporate entrepreneurship and firm } \\
\text { performance: The moderating effect of international } \\
\text { environmental hostility }\end{array}$ & S. A. Zahra and D. M. Garvis & Journal of Business Venturing & $2000 / 332$ \\
\hline $\begin{array}{l}\text { Innovation and the international diffusion of environmentally } \\
\text { responsive technology }\end{array}$ & J. O. Lanjouw and A. Mody & Research Policy & $1996 / 310$ \\
\hline $\begin{array}{c}\text { Business Model Innovation through Trial-and-Error Learning: } \\
\text { The Naturhouse Case }\end{array}$ & $\begin{array}{c}\text { M. Sosna, R. N. } \\
\text { Trevinyo-Rodríguez and S. R. } \\
\text { Velamuri }\end{array}$ & Long Range Planning & $2010 / 305$ \\
\hline $\begin{array}{c}\text { Tipping Toward Sustainability: Emerging Pathways of } \\
\text { Transformation }\end{array}$ & F. Westley et al. & Ambio & $2011 / 274$ \\
\hline $\begin{array}{l}\text { Practical and Innovative Measures for the Control of } \\
\text { Agricultural Phosphorus Losses to Water: An Overview }\end{array}$ & $\begin{array}{l}\text { A. Sharpley, B. Foy and P. } \\
\text { Withers }\end{array}$ & $\begin{array}{l}\text { Journal of Environmental } \\
\text { Quality }\end{array}$ & $2000 / 262$ \\
\hline Innovative capability and export performance of Chinese firms & J. Guan and N. Ma & Technovation & $2003 / 254$ \\
\hline $\begin{array}{l}\text { Lead markets and regulation: a framework for analyzing the } \\
\text { international diffusion of environmental innovations }\end{array}$ & R. Beise and K. Rennings & Ecological Economics & $2005 / 211$ \\
\hline
\end{tabular}

* Y/C-year published/ total citations.

\subsection{Bibliographic Coupling of Publications}

Bibliographic coupling analysis of publications determines the relatedness of publications based on the number of references that they share (Figure 2). The size of the circles represents the number of citations. Meanwhile, the distance represents relatedness and similarities between two publications and the colours represent clusters. Notably, the results meeting a threshold of 50 citations are presented. In total, nine different clusters can be identified (Figure 3). Three clusters are predominating: light blue (right) with the author E. F. Lambin and their citations $(n=1097)$; green cluster (bottom) with the author Q. Zhu and their citations $(n=999)$; and dark blue (top) with the author J. L. Furman and their citations $(n=803)$.

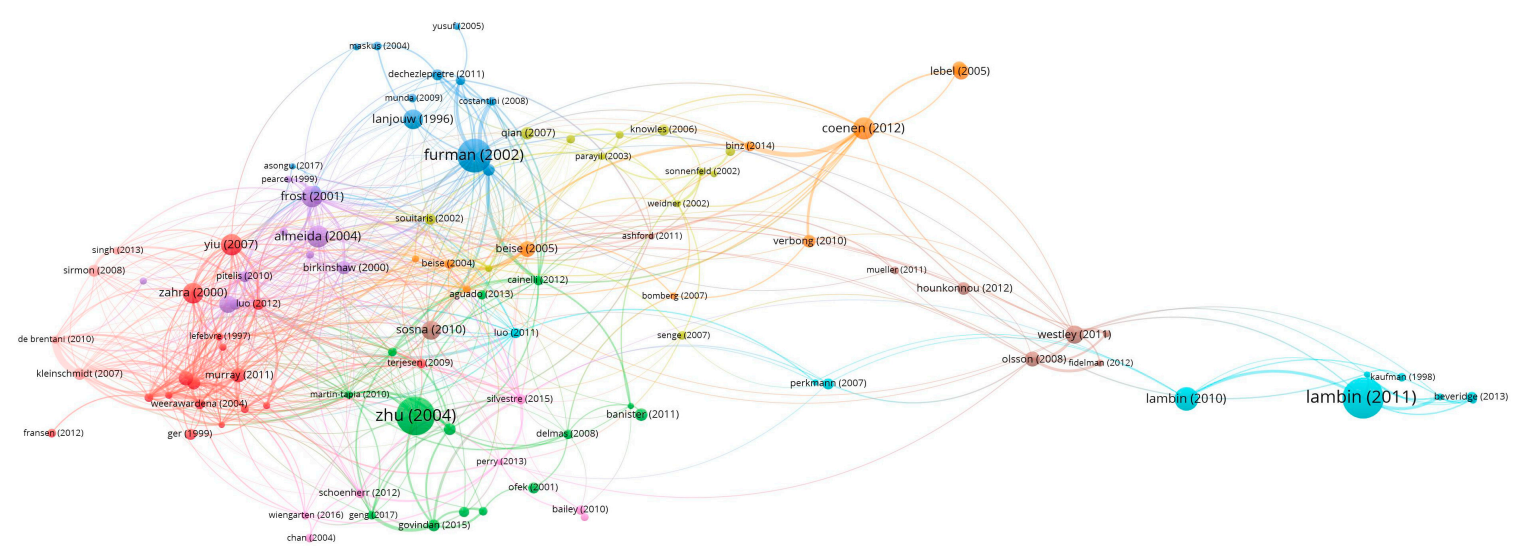

Figure 3. Bibliographic coupling of publications. 


\subsection{The Most Cited Journals}

Aiming to answer RQ2, we analysed the most cited and influential journals. The most cited and influential journals $(n=15)$ on eco-innovations and internationalisation are presented in Table 2 . The most cited journal is Research Policy with 16 documents and is cited in a total of 2210 citations with an average citations per document of $n=138.13$. Second, the most-cited journal is Proceedings of the National Academy of Sciences of the United States of America with 6 documents and in a total of 1476 citations, with average citations per document of $n=246$. Third, the most-cited journal is Journal of Operations Management with 2 documents and in a total of 1476 citations, with average citations per document $n=500$.

Table 2. The most cited publications.

\begin{tabular}{cccc}
\hline Journal & Documents & Citations & Avg. C. per doc. \\
\hline Research Policy & 16 & 2210 & 138.13 \\
Proceedings of the National Academy of Sciences of the United States & 6 & 1476 & 246.00 \\
of America & 2 & 1000 & 500.00 \\
Journal of Operations Management & 4 & 763 & 190.75 \\
Strategic Management Journal & 566 & 113.20 \\
Land Use Policy & 6 & 553 & 92.17 \\
Journal of International Business Studies & 37 & 454 & 12.27 \\
Journal of Cleaner Production & 8 & 423 & 52.88 \\
Ecological Economics & 16 & 419 & 26.19 \\
Technological Forecasting and Social Change & 12 & 393 & 32.75 \\
Energy Policy & 6 & 390 & 65.00 \\
Journal of Product Innovation Management & 5 & 372 & 74.40 \\
Long Range Planning & 8 & 366 & 45.75 \\
Technovation & 2 & 365 & 182.50 \\
Journal of Business Venturing & 17 & 361 & 21.24 \\
\hline International Business Review & & &
\end{tabular}

\subsection{Co-Citation Analysis of Journals}

Co-citation analysis of journals determines the relatedness of the journals based on the number of times they are cited together (Figure 4). The size of the circles represents the number of citations, the distance represents relatedness and similarities between two journals while the colours represent clusters. Notably, only the results meeting a threshold of 50 citations are presented. In total, four different clusters can be identified: the cluster in yellow (the most co-cited in the cluster: American Economic Review $(n=431)$ top left); the cluster in red (the most co-cited in the cluster: Research Policy ( $n=1509)$ bottom left/ middle); cluster in blue (the most co-cited in the cluster: Strategic Management Journal ( $n=1543)$ top right); and cluster in green (the most co-cited in the cluster: Harvard Business Review $(n=459)$ bottom right). The most co-cited journals are: Strategic Management Journal $(n=1543)$, Journal of International Business Studies $(n=1519)$ and Research Policy $(n=1509)$.

\subsection{Co-Citation Analysis of Authors}

Co-citation analysis of authors determines the relatedness of authors based on the number of times they are cited together (Figure 5). The size of the circles represents the number of citations. Meanwhile, the distance represents relatedness, similarities and cooperation between the authors and the colours represent clusters. Only the results meeting a threshold of 20 citations are shown. In total, five different clusters can be identified: cluster in purple (Q. Zhu ( $n=66)$ top left); cluster in red (D. Teece $(n=196)$ left); cluster in blue (J. H. Dunning $(n=144)$ bottom middle); cluster in green (C. Freeman $(n=93)$ bottom right) and cluster in yellow (M. Porter $(n=306)$ top right/ middle). 


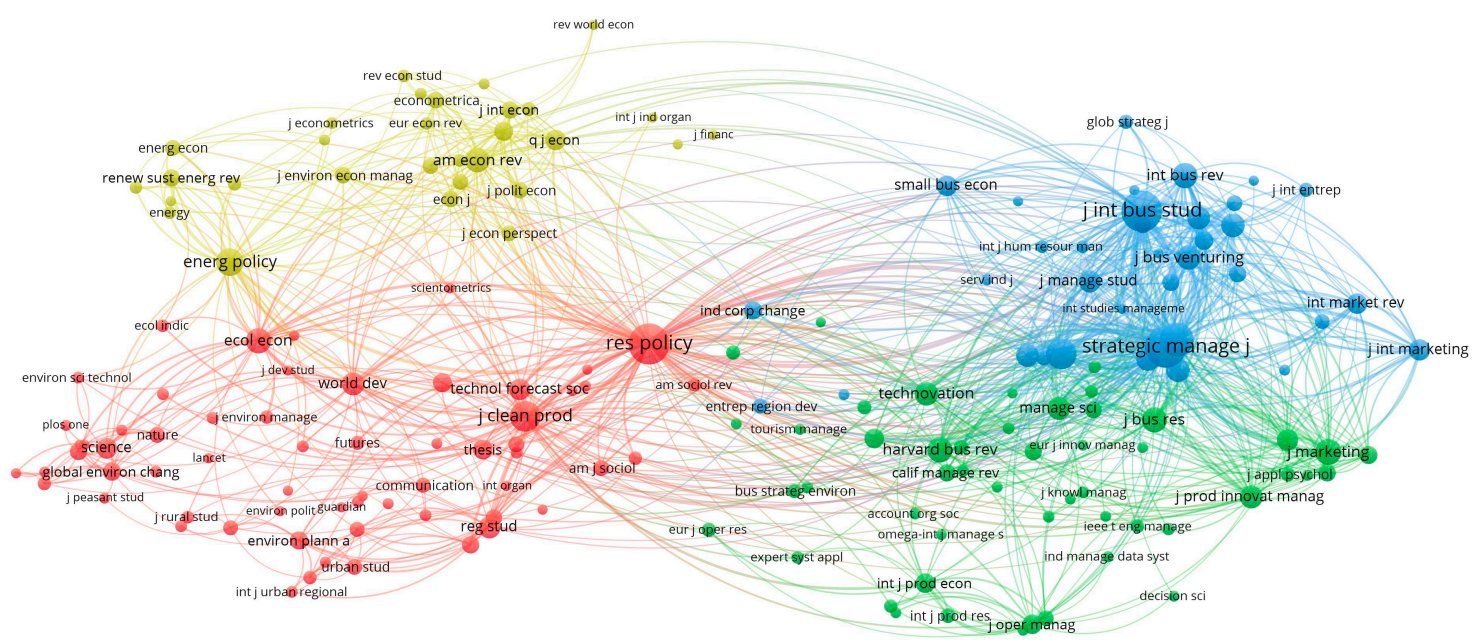

Figure 4. Co-citation analysis of journals.

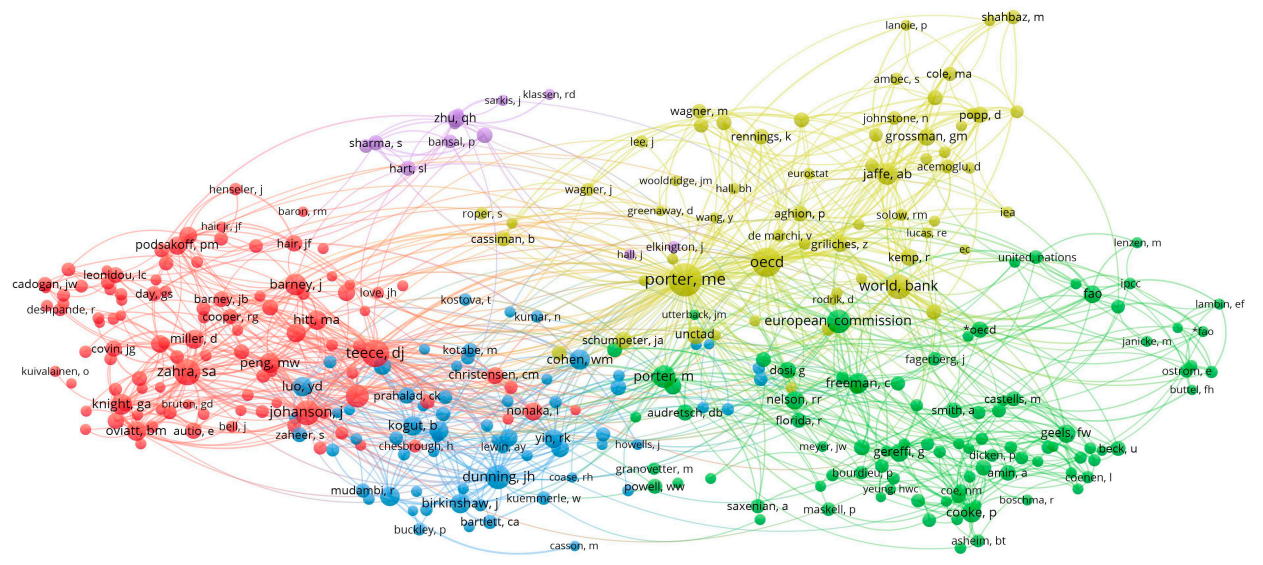

Figure 5. Co-citation analysis of authors.

\subsection{Co-Authorship Analysis of Countries}

To answer RQ2: we analysed the most cited and influential countries. Co-authorship analysis of authors determines the relatedness of countries based on the number of co-authored documents and measures the degree of co-authors between the most productive sources (Figure 6). The size of the circles represents the number of citations. Meanwhile, the distance represents relatedness, similarities and cooperation between countries while the colours represent clusters. In total, six different clusters can be identified: the cluster in yellow (Germany $(n=1061$ citations, documents $n=83)$ left); cluster in green (the United Kingdom ( $n=4631$ citations, documents $n=191$ ) top left/ middle); cluster in purple (France ( $n=976$ citations, documents $n=47)$ top middle); cluster in orange (Taiwan $(n=847$ citations, documents $n=39)$ top right); cluster in red (USA $(n=11,518$ citations, documents $n=320)$ right); cluster in light blue (Spain ( $n=1524$ citations, documents $n=97$ ) bottom middle); and the cluster in dark blue (Netherlands ( $n=2114$ citations, documents $n=61$ ) middle). Only the results meeting a threshold of 10 publications on the topic are shown. The USA is predominating with a total of 320 publications ( $n=11,518$ citations), the United Kingdom is the second largest country ( $n=191$; citations $n=4631$ ) and the People's Republic of China is the third largest country with total of 172 publications ( $n=3468$ citations). 


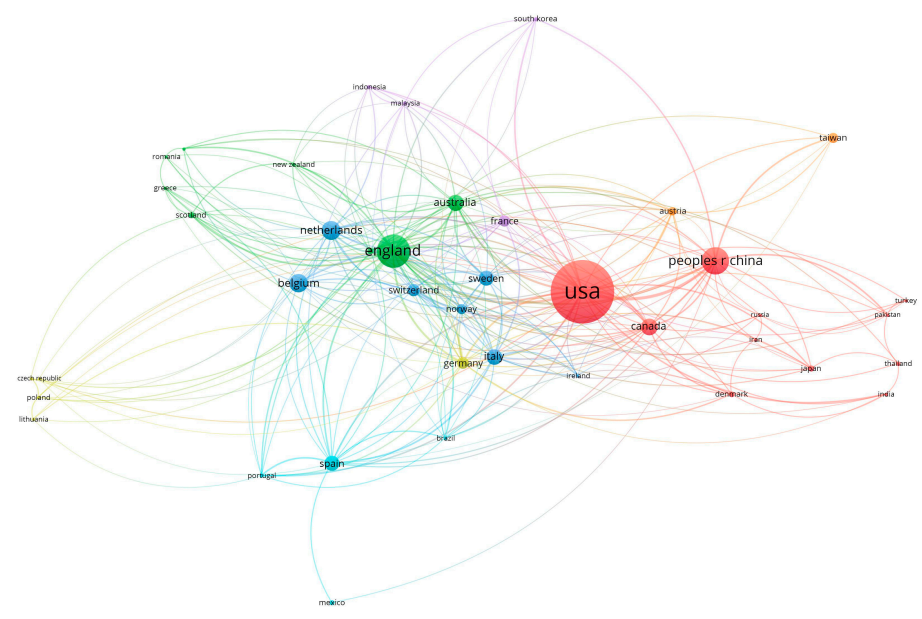

Figure 6. Co-authorship of countries.

\subsection{Keywords}

To answer RQ3, we analysed terms that are being used in scientific documents. Co-occurrence of author's keywords analysis determines the relatedness of keywords based on the number of documents in which authors used specific keywords. Figure 7 reveals common keywords used by authors below the abstract to characterise their papers. The size of the circles represents the number of keywords being used, the distance represents relatedness and similarities between keywords and the colours represent clusters. Notably, only the results meeting a threshold of 15 times are presented. The general noun phrases such as result, study, paper, etc. were extracted from the keyword analysis. In total, seven different clusters can be identified: The cluster in orange ("Globalisation" ( $n=82)$ left middle); cluster in dark blue ("Innovation" ( $n=162)$ top left/middle); cluster in light blue ("Internationalisation" $(n=72)$ top middle); cluster in pink ("Dynamic capabilities" ( $n=18)$ top right); cluster in yellow ("Exports" $(n=27)$ and "Eco-innovation" ( $n=21)$ bottom right); cluster in green ("Sustainable development" $(n=47)$ bottom middle), and the cluster in red ("Competitiveness" ( $n=33$ ) middle right). The most used keywords by authors below the abstracts to characterise the papers on eco-innovations and internationalisation are "Innovation" ( $n=162)$, "Globalisation" ( $n=82)$ and "Internationalisation" ( $n=72)$.

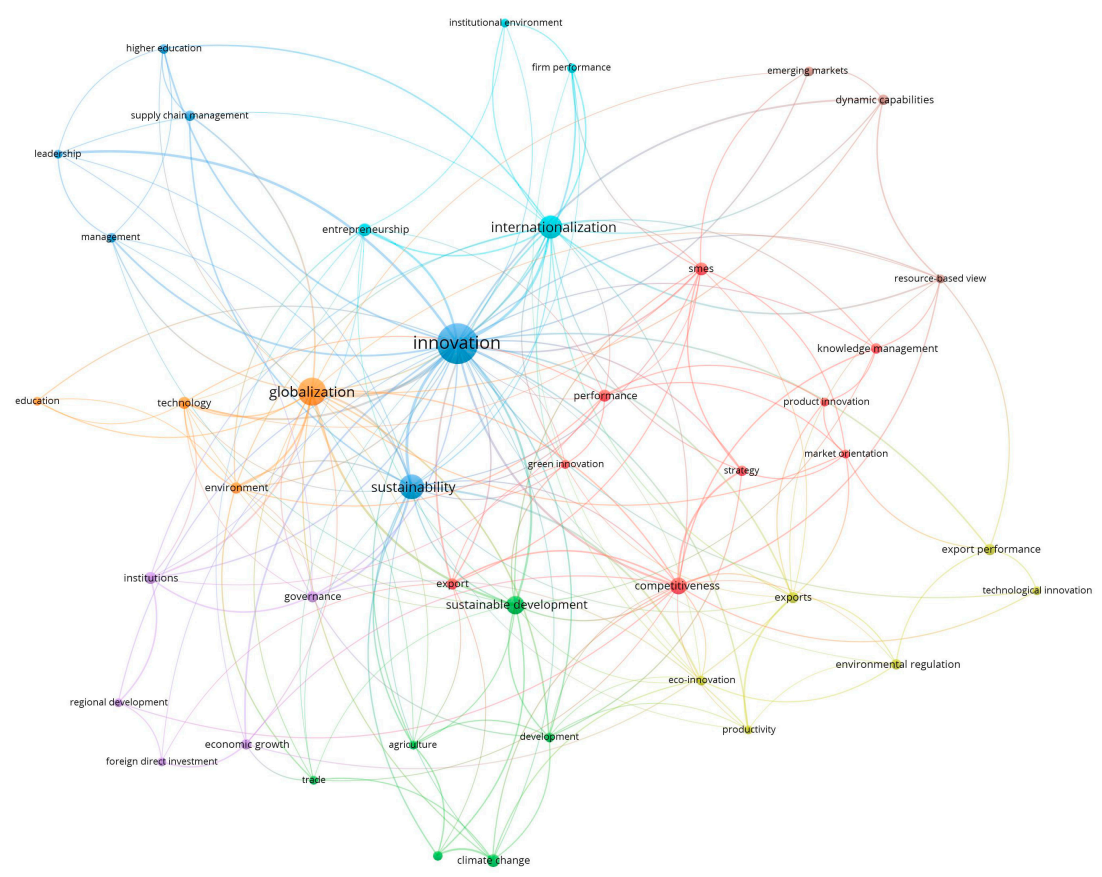

Figure 7. Co-occurrence author keywords. 


\section{Discussion and Limitations}

The analysis of scientific papers on eco-innovations and internationalisation published from 1991 to 2020 is presented. The study includes 1677 publications and covers 4143 authors, 860 journals, 112 countries and 1889 institutions. The academic literature on analysed topics has been increasing during the last ten years. Thus, the publication output is characterised by exponential growth.

- The bibliometric analysis provided information on the most influential and productive scholars in the research field:

- the most cited publication is by authors E. F. Lambin and P. Meyfroidt with an average of 121.89 citations per year;

- the most-cited journal is Research Policy with a total of 2210 citations, the Research Policy journal is also one of the few most co-cited journals with a total of 1509;

- the most co-cited author is M. Porter $(n=306)$;

- the country with the largest publication output is the USA ( $n=11,518$ citations, documents $n=320$ ). Other countries are linked (directly or indirectly) to one of the main countries that are publishing the most scientific documents, thus the data showed that cooperation between authors and countries is mediocre due to the circles' distance from each other; the circles are widely spread, although they are linked together (directly or indirectly).

The power-law distribution lets us observe that:

- $\quad$ the largest proportion of authors (95.70\%) are only credited in one publication;

- a small group of authors (0.73\% of all authors) published at least three papers;

- $\quad$ among the journals publishing the topic, only $6.05 \%$ of journals published more than 5 documents (from a total of 859);

- $\quad$ among all countries (total $n=112$ ) publishing on a topic, $36.61 \%$ countries published over 10 documents;

- a total of 390 publications (23.75\% of all publications) was not (yet) cited;

- a total of 18 publications (1.10\% of all publications) was cited over 200 times.

The distribution corresponds with the study published by van Nunen et al. (2018), which observed that a large proportion of authors, journals and countries do not contribute nearly as much as a much smaller number does and the majority of academic literature is produced by a small group of authors.

Based on author keyword co-occurrence, it is possible to distinguish between four main areas of research: (1) innovations; (2) internationalisation; (3) globalisation; (4) sustainability and sustainable development. Despite its own research stream, all of the main research areas are close to each other in the network analysis and are linked directly together.

The obtained results let us develop the operational model of analysis (Figure 8). The findings of bibliometric analysis and literature review suggest that the rapid growth of globalisation, technology development and digitalisation and sustainable development trends have been impacting the internationalisation process. Moreover, eco-innovation mediates the relationship between internationalisation and financial performance of the firms.

Though bibliometric analysis reduces the bias that is often associated with the expert surveys and traditional reviews, it nevertheless has some limitations. In spite of the benefits for overcoming biases, this method cannot replace rigorous content analysis and overcome its shortcomings, which are that it is a method of quantitative analysis by nature. The number of scientific publications was used as the data in this study. However, it is hardly possible to extensively discuss all the theoretical insights that were presented in the articles. This study is limited to the quantitative method, leaving behind the quality and deeper theoretical knowledge, cornerstones and conclusions presented by the authors in the field of the interrelationship between eco-innovation and internationalisation. Another possible drawback of this study is that citation analysis may be misleading due to authors citing 
some publications in a negative context or self-citations. The last limitation of this study is tied to a selected timeline. For instance, if a similar study would be performed on a different date, the result would be slightly different. The fact that the WoS database is constantly updated with newer scientific documents affects these changes. Furthermore, some important publications may be cited after many years and gain "delayed recognition" in the scientific literature. These limitations can be considered in future studies.

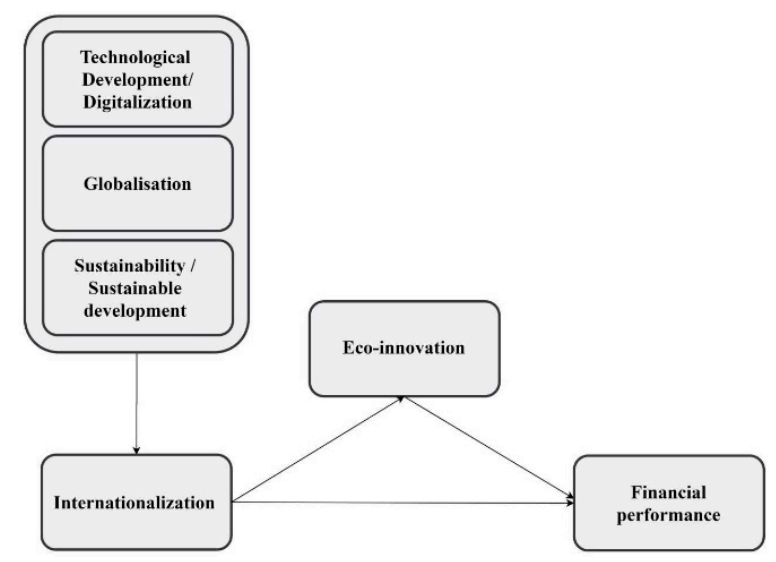

Figure 8. The operative conceptual model of analysis.

\section{Conclusions}

While the expectations of various stakeholders encourage firms to be involved in risky activities, such as the adoption of eco-innovation and internationalisation, we set forth to investigate the interrelationship between eco-innovation and internationalisation by applying bibliometric analysis. The study addressed the research gap emphasising that eco-innovation and internationalisation are barely related factors (Chiarvesio et al. 2015). In total, 1677 publications found in the WoS database that were published between 1991 and 2020 related to eco-innovations and took internationalisation into consideration.

Considering the dynamics in economical, ecological and social environments, we argue that both eco-innovations and internationalisation are closely related and the research trends on interrelationships between eco-innovations and internationalisation study fields are constantly increasing. This is confirmed by the fact of exponential growth of scientific publications on selected topics each year. However, the most influential countries affecting research on these topics are developed countries, such as the USA and the United Kingdom. It appears that the most significant actions on political and company levels are taken toward sustainable development in these countries. However, future investigations have to consider developing countries as well.

We outline a future research agenda to create a more holistic theoretical approach on eco-innovations and internationalisation. By using the fractional counting method for keywords, different trends have been identified involving globalisation and supply chain management. Other interesting interactions between most frequent terms and related to innovation occur for green innovation, technological innovation and product innovation. Thus, future studies should investigate the interrelationships of the selected terms on the dimensions of sustainable development and internationalisation. In addition, other databases such as Scopus have to be taken into account. Also based on the presented limitations of bibliometric analysis, deeper content analysis is recommended for further research.

Author Contributions: Conceptualisation, R.K.; Investigation, P.Š.; Writing-review \& editing, D.Š. All authors have read and agreed to the published version of the manuscript.

Funding: This research received no external funding.

Conflicts of Interest: The authors declare no conflict of interest. 


\section{References}

Bossle, Marilia Bonzanini, Marcia Dutra de Barcellos, Luciana Marques Vieira, and Loïc Sauvée. 2016. The drivers for adoption of eco-innovation. Journal of Cleaner Production 113: 861-72. [CrossRef]

Cainelli, Giulio, Valentina De Marchi, and Roberto Grandinetti. 2015. Does the development of environmental innovation require different resources? Evidence from Spanish manufacturing firms. Journal of Cleaner Production 94: 211-20. [CrossRef]

Cancino, Christian, José M. Merigó, Freddy Coronado, Yasser Dessouky, and Mohamed Dessouky. 2017. Forty years of Computers and Industrial Engineering: A bibliometric analysis. Computers and Industrial Engineering 113: 614-29. [CrossRef]

Chiarvesio, Maria, Valentina De Marchi, and Eleonora Di Maria. 2015. Environmental Innovations and Internationalization: Theory and Practices. Business Strategy and the Environment 24: 790-801. [CrossRef]

Dabić, Marina, Jane Maley, Leo-Paul Dana, Ivan Novak, Massimiliano M. Pellegrini, and Andrea Caputo. 2019. Pathways of SME internationalization: A bibliometric and systematic review. Small Business Economics. [CrossRef]

de Perea, Juan García-Álvarez, Carolina Ramírez-García, and Aida Del Cubo-Molina. 2019. Internationalization business models and patterns of SMEs and MNEs: A qualitative multi-case study in the agrifood sector. Sustainability 11: 2755. [CrossRef]

Deng, Ping, Andrew Delios, and Mike W. Peng. 2020. A geographic relational perspective on the internationalization of emerging market firms. Journal of International Business Studies 51: 50-71. [CrossRef]

Gall, Melanie, Khai Hoan Nguyen, and Susan L. Cutter. 2015. Integrated research on disaster risk: Is it really integrated? International Journal of Disaster Risk Reduction 12: 255-67. [CrossRef]

Genc, Ebru, Mumin Dayan, and Omer Faruk Genc. 2019. The impact of SME internationalization on innovation: The mediating role of market and entrepreneurial orientation. Industrial Marketing Management 82: $253-64$. [CrossRef]

Głodowska, Agnieszka, Bożena Pera, and Krzysztof Wach. 2019. International Strategy as the Facilitator of the Speed, Scope and Scale of Firms' Internationalization. Central European Management Journal 27: 55-84. [CrossRef]

González-Ruiz, Juan David, Sergio Botero-Botero, and Eduardo Duque-Grisales. 2018. Financial eco-innovation as a mechanism for fostering the development of sustainable infrastructure systems. Sustainability 10: 4463. [CrossRef]

Henley, Andrew, and Meng Song. 2019. Innovation, internationalisation and the performance of microbusinesses. International Small Business Journal: Researching Entrepreneurship. [CrossRef]

Hojnik, Jana, Mitja Ruzzier, and Tatiana S. Manolova. 2018. Internationalization and economic performance: The mediating role of eco-innovation. Journal of Cleaner Production 171: 1312-23. [CrossRef]

Inanoglu, Hulusi, and Michael Jacobs Jr. 2009. Models for Risk Aggregation and Sensitivity Analysis: An Application to Bank Economic Capital. Journal of Risk and Financial Management 2: 118-89. [CrossRef]

Juniati, Sri, Mohd Haizam Mohd Saudi, Eriana Astuty, and Norhisham Abdul Mutalib. 2019. The impact of internationalization in influencing firm performance and competitive advantage: The mediating role of eco-innovation. International Journal of Supply Chain Management 8: 295-302.

Korsakienė, Renata, Svajonè Bekešienè, and Šárka Hošková-Mayerová. 2019a. The effects of entrepreneurs' characteristics on internationalisation of gazelle firms: A case of Lithuania. Economic Research-Ekonomska Istrazivanja 32: 2864-81. [CrossRef]

Korsakienè, Renata, Vratislav Kozak, Svajonė Bekešienė, and Rasa Smaliukienè. 2019b. Modelling internationalization of high growth firms: Micro level approach. E+M Ekonomie a Management 22: 54-71. [CrossRef]

Kuo, Tsai-Chi, and Shana Smith. 2018. A systematic review of technologies involving eco-innovation for enterprises moving towards sustainability. Journal of Cleaner Production 192: 207-20. [CrossRef]

Liao, Yi-Chuan, and Kuen-Hung Tsai. 2019. Innovation intensity, creativity enhancement, and eco-innovation strategy: The roles of customer demand and environmental regulation. Business Strategy and the Environment 28: 316-26. [CrossRef] 
Lopes Santos, David Ferreira, Maite Dubugras Valente Rezende, and Leonardo Fernando Cruz Basso. 2019. Eco-innovation and business performance in emerging and developed economies. Journal of Cleaner Production 237. [CrossRef]

Marcus, A. Alfred. 2015. Innovations in Sustainability. Cambridge: Cambridge University Press. [CrossRef]

Martínez-Román, Juan A., Javier Gamero, María de Loreto Delgado-González, and Juan A. Tamayo. 2019. Innovativeness and internationalization in SMEs: An empirical analysis in European countries. Technological Forecasting and Social Change 148: 119716. [CrossRef]

Mi, Lili, Xiao-Guang Yue, Xue-Feng Shao, Yuanfei Kang, and Yulong Liu. 2020. Strategic Asset Seeking and Innovation Performance: The Role of Innovation Capabilities and Host Country Institutions. Journal of Risk and Financial Management 13: 42. [CrossRef]

Munodawafa, Russell Tatenda, and Satirenjit Kaur Johl. 2019. A systematic review of eco-innovation and performance from the resource-based and stakeholder perspectives. Sustainability 11: 67. [CrossRef]

Nguyen, Phuong V., Hien Thi Ngoc Huynh, Hoa Doan Xuan Trieu, and Khoa T. Tran. 2019. Internationalization, Strategic Slack Resources, and Firm Performance: The Case Study of Vietnamese Enterprises. Journal of Risk and Financial Management 12: 144. [CrossRef]

Ociepa-Kubicka, Agnieszka, and Piotr Pachura. 2017. Eco-innovations in the functioning of companies. Environmental Research 156: 284-290. [CrossRef] [PubMed]

Organisation for Economic Cooperation and Development (OECD). 2009. Sustainable Manufacturing and Eco-innovation: Towards a Green Economy. Policy Brief, 1-8. [CrossRef]

Paraschiv, Dorel Mihai, Estera Laura Langă, and Claudia Olaru. 2011. Exploring Eco-innovation Trends in the European Construction Sector. Focus on Romania. The Romanian Economic Journal 14: 69-88.

Paraschiv, Dorel Mihai, Estera Laura Nemoianu, Claudia Adriana Langă, and Tünde Szabó. 2012. Eco-Innovation, Responsible Leadership and Organizational Change for Corporate Sustainability. Amfiteatru Economic Journal 14: 404-19.

Pedro, Eugénia, João Leitão, and Helena Alves. 2018. Back to the future of intellectual capital research: A systematic literature review. Management Decision 56: 2502-83. [CrossRef]

Priede, Janis, and Elisabeth T. Pereira. 2015. European Union's Competitiveness and Export Performance in Context of EU-Russia Political and Economic Sanctions. Procedia—Social and Behavioral Sciences 207: 680-89. [CrossRef]

Przychodzen, Justyna, and Wojciech Przychodzen. 2015. Relationships between eco-innovation and financial performance-Evidence from publicly traded companies in Poland and Hungary. Journal of Cleaner Production 90: 253-63. [CrossRef]

Qi, Wenhao, Zhixiong Huang, Hasan Dinçer, Renata Korsakienè, and Serhat Yüksel. 2020. Corporate Governance-Based Strategic Approach to Sustainability in Energy Industry of Emerging Economies with a Novel Interval-Valued Intuitionistic Fuzzy Hybrid Decision Making Model. Sustainability 12: 3307. [CrossRef]

Ratten, Vanessa. 2018. Eco-innovation and competitiveness in the Barossa Valley wine region. Competitiveness Review: An International Business Journal 28: 318-31. [CrossRef]

Shearmur, Richard, David Doloreux, and Anika Laperrière. 2015. Is the degree of internationalization associated with the use of knowledge intensive services or with innovation? International Business Review 24: 457-65. [CrossRef]

Spaini, Carolina, Paresa Markianidou, and Asel Doranova. 2018. EU Eco-Innovation Index 2018. Technical Note. Technopolis Group. Available online: https://ec.europa.eu/environment/ecoap/sites/ecoap_stayconnected/ files/ecoi_index_eu_2018_technical_note.pdf (accessed on 10 January 2020).

Vahlne, Jan-Erik, and Jan Johanson. 2013. The Uppsala model on evolution of the multinational business enterprise-From internalization to coordination of networks. International Marketing Review 30: 189-210. [CrossRef]

van Eck, Nees Jan, and Ludo Waltman. 2017. Citation-based clustering of publications using CitNetExplorer and VOSviewer. Scientometrics 111: 1053-70. [CrossRef]

van Nunen, Karolien, Jie Li, Genserik Reniers, and Koen Ponnet. 2018. Bibliometric analysis of safety culture research. Safety Science 108: 248-58. [CrossRef] 
Van Raan, Anthony F. J. 2014. Advances in Bibliometric Analysis: Research Performance Assessment and Science Mapping. In Bibliometrics: Use and Abuse in the Review of Research Performance. Edited by Wim Blockmans, Lars Engwall and Denis Weaire. Wenner-Gren International Series; London: Portland Press Ltd., vol. 87, pp. 17-28.

Wang, Bing, Su-Yan Pan, Ruo-Yu Ke, Ke Wang, and Yi-Ming Wei. 2014. An overview of climate change vulnerability: A bibliometric analysis based on Web of Science database. Natural Hazards 74: 1649-66. [CrossRef]

(C) 2020 by the authors. Licensee MDPI, Basel, Switzerland. This article is an open access article distributed under the terms and conditions of the Creative Commons Attribution (CC BY) license (http://creativecommons.org/licenses/by/4.0/). 